\title{
Wrongful birth litigation and prenatal screening
}

\author{
Mark Pioro MA, Roxanne Mykitiuk LLB LLM, Jeff Nisker MD PhD
}

$\mathrm{C}$ anadian clinicians must be aware of new standards of care resulting from national clinical practice guidelines, both to ensure best practice ${ }^{1,2}$ and to avoid malpractice litigation. ${ }^{3,4}$ Clinical practice guidelines can reduce successful malpractice actions through physician education and they may be used in court as evidence that the standard of care was met. ${ }^{5,6}$ The 2007 clinical practice guidelines on prenatal screening for fetal aneuploidy ${ }^{7}$ have expanded the potential for successful wrongful birth litigation and have set a new standard for family physicians, obstetricians, laboratory physicians, radiologists, geneticists, midwives, registered nurses, genetic counselors and ultrasound technicians.

The clinical practice guidelines on prenatal screening were endorsed by the Society of Obstetricians and Gynaecologists of Canada and the Canadian College of Medical Geneticists. The guidelines include the recommendation that all pregnant women be offered prenatal screening, rather than just women aged 35 years or more (Box 1), ${ }^{7,8}$ the age at which the risk of losing a fetus as a complication of an amniocentesis is equal to the risk of giving birth to a child with Down syndrome. ${ }^{7}$ This recommendation was in response to the observation that $56 \%$ of women who give birth to a child with Down syndrome are under 35 years of age. ${ }^{7}$ New sensitive and noninvasive screening strategies have made this recommendation possible. ${ }^{9-13}$ Recent clinical practice guidelines in the United Kingdom, ${ }^{14}$ Australia, ${ }^{15}$ New Zealand ${ }^{15}$ and the United States, ${ }^{16}$ have similarly recommended offering of screening for Down syndrome to all pregnant women. It is too early to evaluate the legal impact of such clinical practice guidelines in these jurisdictions.

In the past, wrongful birth claims in Canada have been successful when prenatal screening was not offered to a woman over 35 years of age who gave birth to a child with Down syndrome and who asserted that, if not for this negligence, she would have chosen to abort the fetus. ${ }^{17-19}$ For example, in one successful claim, a 37-year-old woman requested amniocentesis in her sixteenth week of pregnancy and was told by her physician that it was too late in the pregnancy. ${ }^{17}$ In another successful claim, a 36-year-old woman seeking prenatal care from her family physician was not told that he did not practice prenatal care ${ }^{18}$ and she was not referred to another physician. Canadian legal scholars have predicted that there will be an increase in this type of legal action $^{4}$ and that the courts will rule against physicians if they do not offer prenatal tests if they become standard practice. ${ }^{20}$ However, according to the Canadian Medical Association Code of Ethics, ${ }^{21,22}$ duties, such as offering prenatal screening, exist alongside the duty of physicians to practice in compli-

\section{Key points}

- Successful wrongful birth litigation may increase in Canada if clinicians do not practise according to the new clinical practice guidelines.

- A clinician may be legally liable if prenatal screening is not offered.

- The new guidelines emphasize obligations of respect for reproductive autonomy and respect for disabled people; however, tension exists between these obligations because clinicians may be legally liable if prenatal screening is not offered.

- Research into the implications of the guidelines on Canadian clinicians, pregnant woman, disabled people and the general public is required.

- Canadian professional bodies should work together to provide information to clinicians about informed consent, nondirective counselling and sensitivity to both people with disabilities and pregnant women.

- Professional societies should offer courses that include a discussion of the new standards and resulting counselling obligations.

ance with their conscience, as long as she or he provides sufficient notice to the patient to see another physician. ${ }^{21,22}$

In this article, we aim to inform clinicians of the legal implications of the new clinical practice guidelines on prenatal screening. We also discuss the implication of these guidelines on how pregnant women may perceive prenatal screening and their pregnancies, and how people with genetic conditions, congenital anomalies and disabilities may be viewed by others and themselves.

\section{Negligence and prenatal screening}

Tort law provides compensation to those who have been harmed as a result of a breach of a legal duty. ${ }^{23}$ Negligence is the breach of legal duty that involves the creation of "unreasonable risk" ${ }^{24}$ that results in damage that could have been avoided through "reasonable care." Determining reasonable care is often determined in court proceedings. ${ }^{25}$ The Supreme Court of Canada has held that "physicians have a duty to conduct their practice in accordance with the conduct of a prudent and diligent doctor in the same circumstances." ${ }^{26}$ In the case of a specialist, his or her actions must be assessed in light of the conduct of other specialists "who possess a rea-

From Osgoode Hall Law School (Pioro, Mykitiuk), York University, Toronto, Ont.; and the Schulich School of Medicine \& Dentistry (Nisker), The University of Western Ontario, London, Ont. 
Box 1: Relevant recommendations from the new Canadian guideline on prenatal screening?

- All pregnant women should be offered prenatal screening for common fetal aneuploidies, and a second trimester ultrasound for dating, growth and anomalies.

- An informed consent process should occur.

- Health care providers should be aware of screening modalities available in their province or territory.

- Screening programs should respect the needs and quality of life of disabled persons.

- Counselling should be nondirective and should respect a woman's choice regarding all options.

sonable level of knowledge, competence and skill expected of professionals in Canada, in that field." ${ }^{26}$ Although clinical practice guidelines establish the standard of care and provide evidence as to what conduct may be considered reasonable, they do not necessarily establish the legal standard of care. The ultimate determination of the legal standard of care lies with the court after consideration of all evidence., ${ }^{3,27}$

\section{Duty of disclosure}

As part of the duty to ensure informed consent, clinicians must disclose to their patients the risks associated with health conditions and medical procedures. ${ }^{28}$ This obligation arises out of the " "special' relationship between a physician and a patient where, due to the physician's superior medical knowledge and skill, the patient must place 'trust and confidence' in the physician." ${ }^{29}$

What information a reasonable doctor should provide depends on the medical knowledge and practices currently available. ${ }^{28}$ Although professional practice guidelines, as supported at trial by expert testimony, can articulate the information that should be provided, courts do not base decisions in claims about lack of informed consent solely on the reasonable-doctor standard. ${ }^{28}$ Rather, they include evidence from the patient and family members about the risks of which the patient requires disclosure. ${ }^{28}$ Moreover, a burden is "placed on the doctor to show that the patient comprehended the explanation and instructions given." ${ }^{30}$ Though some have criticized this standard as too onerous, ${ }^{31}$ it remains the law as prescribed by the Supreme Court of Canada. The patient may argue that the risks to which a reasonable patient would be likely to attach significance when deciding whether to undergo the proposed treatment, that is, that the "material risks" (as defined by the Supreme Court of Canada) were not presented or understood. ${ }^{32}$

\section{Causation and compensable loss in wrongful birth claims}

In order to be compensated in a wrongful birth litigation, the mother must demonstrate that her prenatal care provider negligently failed to offer or perform prenatal screening. She must also establish that a reasonable person in her position would have terminated the pregnancy if prenatal screening had been properly offered and performed. ${ }^{33}$

The court must ask whether the birth of a child can constitute a loss that can be compensated for. ${ }^{34,35}$ The birth must be argued to be associated with pain and suffering of the parents, as well as with their loss of income and expenses related to raising a child with a disability. ${ }^{36}$

\section{Impact on pregnant women}

With the development of amniocentesis, women can exercise reproductive choice - they can choose to avoid giving birth to a child with Down syndrome or another genetic-based condition. However, the availability of prenatal screening and the fact that it is being offered by a physician, carries normative implications about the desirability of prenatal screening. ${ }^{37}$ Further, the implication that prenatal screening is desirable may be promoted if physicians present prenatal screening as routine..$^{38-40}$ The combination of this ability to choose and the legally sanctioned concept that the birth of a disabled child can constitute a harm may cause a woman to be viewed as harming a child simply by choosing to bring a disabled child to term. ${ }^{41,42}$ Rothman has argued that in the era of prenatal testing, every pregnancy may be considered tentative. ${ }^{38}$ She cautions that women may be considered bad mothers for bringing a disabled child into the world..$^{38}$

\section{Impact on disabled people}

The new clinical practice guidelines about fetal aneuploidy ${ }^{7}$ state that "Screening programs should show respect for the needs and quality of life of persons with disabilities. Counselling should be nondirective and should respect a woman's choice to accept or to refuse any or all of the testing or options offered at any point in the process." The critique of prenatal testing based on the rights of disabled people illustrates the importance of this recommendation and the challenge to following it successfully. ${ }^{43-47}$

Some argue ${ }^{43}$ that prenatal testing "sends the hurtful message that people are reducible to a single, perceived-to-be-undesirable trait" 43 and when "a single trait stands in for the whole, the trait obliterates the whole. ${ }^{\prime 43}$ Through the prenatal screening lens, disabled people may be viewed as living lives of low quality, ${ }^{44}$ despite their often-expressed views to the contrary. ${ }^{45}$ Although important progress has been made in the protection of the rights of disabled people, the practice of prenatal screening may encourage the view that it is better to prevent their existence rather than to remove the social barriers they face..$^{41,46,48}$ Similarly, prenatal screening may strengthen the idea that a person should meet a certain level of "fitness" to be born.

Wrongful birth claims may contribute to the perception that the birth of a disabled child is a burden to the parents and the community as well as to the child. The law's recognition of wrongful birth actions may deny the reality that disability is largely socially constructed..$^{41,42,44}$ This may have a negative impact on the psychological well-being of disabled people. ${ }^{49}$

Proponents of prenatal screening argue that in considering the financial and other costs associated with raising a child 
with a severe disability, it is reasonable for potential parents to consider preventing the birth. ${ }^{50}$ Further, since there are many reasons to receive prenatal screening, the practice in itself does not convey any distinct message about the value of the lives of disabled people. ${ }^{50,51}$ Some argue that objections to prenatal screening are not sufficiently distinguishable from objections to abortion. ${ }^{51}$ Similarly, those who believe wrongful birth actions are appropriate contend that they do not devalue the lives of people with disability. ${ }^{35,52,53}$

\section{Exploring the tensions}

The clinical practice guidelines on prenatal screening for fetal aneuploidy specifically expresses the need for screening programs to be respectful of women's choices regarding screening and the implications. They must also respect the needs and the quality of life of disabled people. However, if a pregnancy is terminated because of predicted anomalies, tension may exist between respect for women's reproductive choice and respect for disabled people. This tension is amplified if physicians are legally liable if they do not offer prenatal screening to all pregnant women in their care and if a child is born with a condition that could have been predetermined. Many scholars and activists concerned with the rights of disabled people strongly oppose both prenatal screening and wrongful birth claims for this reason. They are also opposed to screening and wrongful birth claims because both the guidelines and any resulting successful wrongful birth claims potentially ignore the many traits of personhood the child brings in being born, as well as the traits of personhood of those already living with disabilities in that jurisdiction and beyond. ${ }^{41,43,44,48}$

Although the increase in reproductive decisions women will face following the increase in screening will be justified as an exercise of reproductive choice, such increases may also result in more women viewing their pregnancies as tentative ${ }^{38}$ until the results of prenatal screening are known. Further, the existence of wrongful birth claims reinforces the view that the birth of a child with a disability is a harm for which one may be compensated. ${ }^{41}$

In addition to the new guidelines, there should also be professional development for clinicians about how to provide nondirective counselling ${ }^{29}$ about prenatal screening and how to be sensitive to the position of disabled people. This should include information about support networks, social programs aimed at supporting and accommodating people with disabilities and referrals to groups, families or people living with the diagnosed condition who can provide information about and options for caring for children with the condition. In addition, there should be public education about the views of the community of disabled people. Research into the effect of the new clinical practice guidelines is required and should involve clinicians, patients, disabled people, professional organizations and the public.

\section{Conclusion}

In Canada, wrongful birth claims may increase if clinicians do not practise according to the new standard of care prescribed in the 2007 clinical practice guidelines on prenatal screening for fetal aneuploidy, which includes offering prenatal screening to all pregnant women. Although these guidelines emphasizes the obligation of respect for reproductive autonomy and for disabled people, the fact that a clinician may be legally liable if prenatal screening is not offered to a pregnant woman and her child is born with a condition that could have been predetermined promotes tension between these obligations.

This article has been peer reviewed.

Competing interests: None declared.

Contributors: All of the authors contributed to the content of the article, revised it critically and approved the final version submitted for publication.

\section{REFERENCES}

1. US Institute of Medicine, Committee to Advise the Public Health Service on Clinical Practice Guidelines. Clinical practice guidelines: directions for a new program. Washington (DC): National Academy Press; 1990.

2. Battista RN, Hodge MJ. Clinical practice guidelines: between science and art. CMAJ 1993;148:385-9.

3. Campbell A, Cranley Glass K. The legal status of clinical and ethics policies, codes, and guidelines in medical practice and research. McGill Law J 2001;46:473-89.

4. Caulfield T. Liability in the genetic era: wrongful birth and wrongful life lawsuits. J Obstet Gynaecol Can 2001;23:143-7.

5. Rinella L. The use of medical practice guidelines in medical malpractice litigation - should practice guidelines define the standard of care? University of Missour Kansas City Law Review 1995;6:337-55.

6. DeJong v. Owen Sound General and Marine Hospital (1996), 31 OR (3d) 594 (Gen Div).

7. Summers AM, Langlois S, Wyatt $\mathrm{P}$, et al. Prenatal screening for fetal aneuploidy. $J$ Obstet Gynaecol Can 2007;29:146-79.

8. Chodirker BN, Cadrin C, Davies GAL, et al. Canadian guidelines for prenatal diagnosis: genetic indicators for prenatal diagnosis. J Obstet Gynaecol Can 2001;23:525-31

9. Orlandi F, Damiani G, Hallahan TW, et al. First-trimester screening for fetal aneuploidy: biochemistry and nuchal translucency. Ultrasound Obstet Gynecol 1997;10:381-6.

10. Wald NJ, Rodeck C, Hackshaw AK, et al. First and second trimester antenatal screening for Down's syndrome: the results of the Serum, Urine and Ultrasound Screening Study (SURUSS). J Med Screen 2003;10:56-104.

11. Malone FD, Canick JA, Ball RH, et al. First- and Second-Trimester Evaluation of Risk (FASTER) Research Consortium. First-trimester or second-trimester screening, or both, for Down's syndrome. N Engl J Med 2005;353:2001-11.

12. Aitken DA, Wallace EM, Crossley JA, et al. Dimeric inhibin A as a marker for Down's syndrome in early pregnancy. N Engl J Med 1996;334:1231-6.

13. Nicolaides KH, Azar G, Byrne D, et al. Fetal nuchal translucency: ultrasound screening for chromosomal defects in first trimester of pregnancy. $B M J$ 1992;304:867-9.

14. UK National Screening Committee policy position. The Committee; 2006 Available: www.nsc.nhs.uk/pdfs/policy_position_chart_july06\%5B1\%5D.pdf (accessed 2008 Aug 29).

15. The Royal Australian New Zealand College of Obstetricians and Gynaecologists. Prenatal screening tests for trisomy 21 (Down syndrome), trisomy 18 (Edwards syndrome) and neural tube defects. East Melbourne (Australia): The College; 2007. Available: www.ranzcog.edu.au/publications/statements/C-obs4.pdf (accessed 2008 Aug 29)

16. ACOG practice bulletin no. 77: Screening for fetal chromosomal abnormalities. Obstet Gynecol 2007;109:217-27.

17. Zhang v. Kan (2003) BCSC 5.

18. Krangle (guardian of) v. Brisco (1997), 154 DLR. (4th) 707 (BCSC)

19. Jones v. Rostvig (2003), BCSC 1222

20. Ossorio PN. Prenatal genetic testing and the courts. In: Parens E, Asch A, editors. Prenatal testing and disability rights. Washington (DC): Georgetown University Press; 2000. p. 308-33.

21. Canadian Medical Association. CMA code of ethics. Ottawa (ON): The Association; 2004. Available: http://policybase.cma.ca/PolicyPDF/PD04-06.pdf (accessed 2008 Aug 29).

22. Medicine. In: Canadian encyclopedic digest. Toronto (ON): Carswell; 2008. Paragraph $\S 109$.

23. Rogers WVH. Winfield and Jolowicz on tort. 14th ed. London (UK): Sweet and Maxwell; 1994.

24. Weinrib EJ. Tort law: cases and materials. 2nd ed. Toronto (ON): Emond Montgomery; 2003.

25. M'Alister (or Donoghue) v. Stevenson, [1932] AC 562 (HL).

26. Ter Neuzen v. Korn (1995), 127 DLR (4th) 577 (SCC). 
27. Merenstein D. Winners and losers. JAMA 2004;291:15-6.

28. Reibl v. Hughes, [1980] 2 SCR 880.

29. Sharpe N. Reinventing the wheel? Informed consent and genetic testing for breast cancer, cystic fibrosis, and Huntington disease. Queen's Law J 1997;22:389-452.

30. Ciarlariello v. Schacter, [1993] 2 SCR 119.

31. Byciuk v. Hollingsworth (2004), ABQB 370.

32. Medicine. In: Canadian Encyclopedic Digest. Toronto (ON): Carswell; 2008. paragraph $\$ 123$.

33. Arndt v. Smith, [1997] 2 SCR 539.

34. Akazaki L. "Wrongful birth": an ironic name for a cause of action in the law of medical malpractice. The Advocate's Quarterly 1999;22:102-8. Available: http://www.gilbertsondavis.com/publications/wrongful\%20birth.htm (accessed 2008 Sept 4)

35. Dimopoulos P, Bagaric M. Why wrongful birth actions are right. J Law Med 2003;11:230-8.

36. Kealey v. Berezowski (1996), 30 OR (3d) 37 (Gen Div).

37. Jennings B. Technology and the genetic imaginary: prenatal testing and the construction of disability. In: Parens E, Asch A, editors. Prenatal testing and disability rights. Washington (DC): Georgetown University Press; 2000. p. 124-456.

38. Katz Rothman B. The tentative pregnancy: prenatal diagnosis and the future of motherhood. New York (NY): Viking; 1986.

39. Nisker JA. Orchids: Not necessarily a gospel. In: Murray J, editor. Mappa mundi: mapping culture/mapping the world. Windsor $(\mathrm{ON})$ : University of Windsor Press; 2001. p. 61-109.

40. Mykitiuk R. Public bodies, private parts: genetics in a post-Keynesian era. In: Cossman B, Fudge J, editors. Privatization, law, and the challenge to feminism. Toronto (ON): University of Toronto Press; 2002. p. 311-54.

41. Hensel WF. The disabling impact of wrongful birth and wrongful life actions. Harv Civ Rights-Civil Lib Law Rev 2005;40:141-96. Available: www.law.harvard .edu/students/orgs/crcl/vol40_1/hensel.pdf (accessed 2008 Sept 4).

42. Botkin JR. Prenatal diagnosis and the selection of children. Fla State Univ Law Rev 2003;30:265-94

43. Parens $\mathrm{E}$, Asch $\mathrm{A}$, editors. The disability rights critique of prenatal genetic testing: reflections and recommendations. Prenatal testing and disability rights. Washington (DC): Georgetown University Press; 2000. p. 3-43.

44. Wasserman D, Bickenbach J, Wachbroit R, editors. Introduction. Quality of life and human difference: Genetic testing, health care, and disability. New York: Cambridge University Press; 2005. p. 1-26.

45. Amundson R. Disability, ideology, and quality of life: a bias in biomedical ethics. In: Wasserman D, Bickenbach J, Wachbroit R, editors. Quality of life and human difference: Genetic testing, health care, and disability. New York: Cambridge University Press; 2005. p. 101-24.

46. Saxton M. Disability rights and selective abortion. In: Solinger R, editor. Abortion wars: A half century of struggle, 1950-2000. Berkeley (CA): University of California Press; 1998. p. 374-94.

47. Asch A, Wasserman D. Where is the sin in synecdoche? Prenatal testing and the parent-child relationship. In: Wasserman D, Bickenbach J, Wachbroit R, editors. Quality of life and human difference: Genetic testing, health care, and disability. New York (NY): Cambridge University Press; 2005. p. 172-216.

48. Sheth DM. Better off unborn? An analysis of wrongful birth and wrongful life claims under the Americans with Disabilities Act. Tenn Law Rev 2006;73:641-68.

49. Wexler DB. International network on therapeutic jurisprudence. Tucson (AZ): The University of Arizona. James E. Rogers College of Law; 2007. Available: www.law.arizona.edu/depts/upr-intj/ (accessed 2008 Aug 29).

50. Steinbock B. Disability, prenatal testing, and selective abortion. In: Parens E, Asch A, editors. Prenatal testing and disability rights. Washington (DC): Georgetown University Press; 2000. p. 108-23.

51. Nelson JL. The meaning of the act: reflections on the expressive force of reproductive decision making and policies. In: Parens E, Asch A, editors. Prenatal testing and disability rights. Washington (DC): Georgetown University Press; 2000. p. 196-213.

52. Shapira A. "Wrongful life" lawsuits for faulty genetic counseling: the impaired newborn as a plaintiff. Tel Aviv Studies in Law 1997;13:97-114.

53. Stretton D. The birth torts: damages for wrongful birth and wrongful life. Deakin Law Review 2005;10:319-64.Available: www.austlii.edu.au/au/journals/DeakinLRev /2005/16.html\#Heading6 (accessed 2008 Aug 29).

Correspondence to: Dr. Jeffrey Nisker, London Health Sciences Centre, 339 Windmere Rd., London ON N6A 5A5;

fax519663-3808; jeff.nisker@lhsc.on.ca

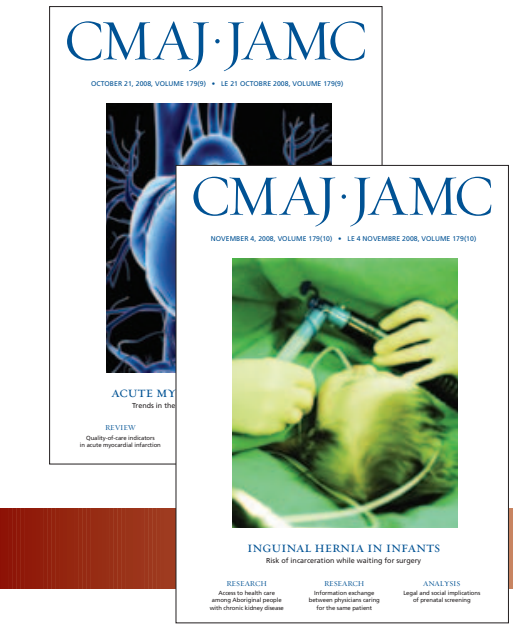

\section{Online manuscript submission and peer review available for $C M A J$}

